UDC 821.111(73)-1'42

\title{
CONTINUOUS FORM IN AMERICAN POETIC DISCOURSE OF THE XXI CENTURY
}

O. V. Popova, PhD, Associate Professor

https://orcid.org/0000-0002-1851-2931

J. Lazutkina, Student

Sumy State University

2, Rymskogo-Korsakova St., Sumy, 40007, Ukraine

E-mail:o.popova@gf.sumdu.edu.ua; lazutkinayulia@gmail.com

The article deals with the research of American poetic discourse of XXI century with the further estimation of the role performed by the category of aspect in the process of this discourse molding. The rationale of the chosen topic is dictated first of all by the dominant position of the functional paradigm in the modern linguistics, and thus by special attention addressed to the study of language units and their "deepening into life», and to interconnection of language and speech levels within the discourse.

The situation described in the poem is connected with the situation when the poem is being created by the artist. Thus, the reader gets two tasks: to interpret the information given by means of poetic images, and, as much as it is possible, to deepen into the situation, in which the whole poem was created, to find out possible information about the addresser, his surrounding, position, etc. To deepen into the situation there is Continuous form of the verb, which is observed as a cross point for category of tense and category of aspect and helps to mold the poetic discourse.

The article is written within the research topic «Mechanisms of Civil Society Influence upon Euro-Integration Processes in Ukraine» №15.01.10-02.16/18.3П.

Key words: addresser, addressee, Continuous form of the verb, category of aspect, category of tense, grammatical meaning, lexical meaning, poetic discourse

https://doi.org/10.21272/Ftrk.2018.10(3)-10

Our life comprises numerous events. Everything happening to us is happening right now. Nothing can happen yesterday, nothing can happen tomorrow. We always live «today» and always «at this very moment». For example, at this very moment, we are working at a research paper. Yesterday, it was just an intention and a plan, tomorrow, it will be a memory, but today, this is the very action, thus, this is the very life.

Writers of all the centuries tried to reproduce such moments in their literary works, to describe them as brightly as possible, to make readers, that would take this book in 100 or 200 years, dive in the situation where the authors were, to make these addressees feel emotions, the same as addressers' ones. During the processes of writing or perceiving the text, both a writer and a reader are affected by numerous factors, such as their mood, surrounding, location, ethnic origin, personal experience, social status, even weather, season, amount of light and warmth, etc. Therefore, the created and received text ceases to be just a bunch of words on paper, it acquires more and more new features, tinges, senses.

This is a communicative event that modern linguists call «discourse» defining this term differently in numerous ways. The discourse was researched by M. Akishyna, N. Arutiunova, Z. Bandurko, R. Bart, F. Batsevych, T. van Dyke, V. Demiankov, I. Kobiakova, O. Zabolotska, V. Krasnykh, O. Popova, O. Rusakova, etc. The following researchers are interested in American poetic texts: L. Belekhova, O. Zabolotska, V. Nenko and others. The peculiarities of the category of aspect and Continuous tenses usage were investigated by B. Ilyish, B. Khaimovych, O. Jespersen, A. G. Kennedy, etc.

The article deals with the research of American poetic discourse of the XXI century with further estimation of the role performed by the category of aspect in the process of this discourse molding. The rationale of the chosen topic is dictated first of all by the dominant position of the functional paradigm in the modern linguistics, and thus by special attention

(C) Popova O. V., Lazutkina J., 2018 
addressed to the study of language units and their «deepening into life», and to interconnection of language and speech levels within the discourse.

The article is aimed at analyzing the role of category of aspect in the American poetic discourse molding in the XXI century. In order to achieve this goal, the following tasks should be fulfilled: 1) to define the American poetic discourse of the XXI century, its functions and features, 2) to analyze the ways of expressing the category of aspect in the American poetic discourse of the XXI century, 3) to calculate the ration of tense-aspect forms in poetic texts, 4) to discover lexico-grammatical meaning of the category of aspect in the American poetic discourse of the XXI century.

To achieve the aim and fulfill the tasks, the following methods were applied:

- while material collecting there was used the method of complete sample,

- the material was analyzed with the help of the complete analysis method, descriptive research, contextual analysis, comparison method, and generalization.

The object of the study is the modern American poetic discourse and the category of aspect within this discourse. The peculiarities of Continuous Tense usage in the poetic texts and its role in the poetic discourse molding present the subject of the study.

The category of tense is peculiar to the English verb. As M. Blokh says, «it is necessary to strictly distinguish between the general notion of time, the lexical denotation of time, and the grammatical time proper, or grammatical temporality» [1, p. 137]. Time is one of the features of the reality independent of people and their perception, but the person perceives and translates it into the language. In the language, the moment of speech is a reference point allowing to distinguish the past and the future, a completed action and an incompleted one [1, p. 137]. The category of tense is one of the important categories of the verb showing the time-frame in the language. Of course, there are lexical units denoting a particular time but only when going along with a verb in the relevant tense-form, they convey the sense adequately. This can be seen as in the following examples:

- In 2006, she entered the university.

- In 2006, she will enter the university.

Despite the fact that the particular time «in 2006» is mentioned, this is the verb that defines the moment of speech. In the first sentence, this is the time after 2006, and in the second sentence, this is the time before 2006. The proposal can be misunderstood without the relevant tense form of the verb. So, the tense form of the verb plays a significant role in the language and speech. The very name of the verb as a part of speech is connected with the notion of time in some languages: das Zeitwort (literally «word of the time») in German, czasownik (from the word «czas» - «time») in Polish.

There is no consensus among linguists on belonging of the Continuous form either to the category of tense or to the category of aspect. According to B. Khaimovych and B. Rogovska, there are the following approaches to the category of aspect:

1. «Aspect is interpreted as a category of semantics rather than that of grammar» $[2$, p. 135, 3, p. 303, 304]. This point of view is supported by M. Deutschbein, J. O. Kerm, etc. That is true that the semantic component cannot be neglected in the process of the category of aspect expression. The Continuous Tense category can be grammatically expressed with the help of the model: to be + Ving. For example, in the sentence «Someone is in the kitchen washing the dishes» [4], the duration of the action is expressed through the grammatical form of the verb: is washing. When changing the grammatical form of the verb, we will change the meaning of the sentence as well, e.g., "Someone washes the dishes in the kitchen». In the first variant, the action is lasting at some particular moment, while in the second variant, the action seems to be a regular and repetitive one.

2. "Aspect is not recognized at all as a category of Modern English grammar» [2, p. 135; 5, p. 180]. As H. Sweet and O. Jespersen believe, the category of aspect cannot exist as the Continuous form shows that the action is developing at the same time with another action [2, p. 135]. The Continuous form, however, does not always convey the meaning of simultaneousness. Firstly, the category of aspect has other grammatical meanings causing 
changes in the semantic component (e.g. duration, planning), and secondly, such a form as Perfect Continuous includes no duration-meaning:

\author{
My heart like a drum \\ In your skillful hands \\ Beats in rhythms you stroke \\ That one song. \\ I've been living for [6].
}

B. Khaimovych and B. Rogovska do not support this approach as well.

3. «Aspect and tense are recognized as two distinct grammatical categories» [2, p. 135]. The idea, that the Countinous form is an expression of the aspect only, but not of the tense, cannot be truthful. And this can be proved by the following examples: She will proofread her paper. - She will be proofreading her paper. Both forms will proofread and will be proofreading express the Future Tense.

4. «Aspect is blended with tense and regarded as an inalienable part of the tense-aspect system» $[2$, p. 135, 7, p. 162]. This approach seems to be the most correct one. The Continuous form is regarded as a point where the category of aspect and the category of tense are combined. M. Blokh proves this idea: «The combined temporal-aspective interpretation of the continuous, in general, should be appraised as an essential step forward, because, first, it introduced on an explicit, comprehensively grounded basis the idea of aspective meanings in the grammatical system of English; second, it demonstrated the actual connection of time and aspect in the integral categorial semantics of the verb» $[1$, p. 160].

Thus, the Continuous model «to be + Ving» is extremely rich in different lexicogrammatical meanings:

- Sunshine is slowly edging rain [8] - duration of the action;

- While we were waiting for her surgery to finish, / I walked around the hospital... [4] - simultaneousness of two actions;

- You have a student who is constantly disrupting the class by talking out of turn and exhibiting off-task behavior during direct instruction and collaborative group work [9] repetition of the action;

- The President of Ukraine is arriving in Georgia today (in this case, the form denotes the Future Tense) [10] - the planned action;

- The government is going to counter 'misinformation' about GMO foods [11] - an intention to do something.

So, the Continuous form can be approached in different ways. The most appropriate approach is considering the category of aspect to be blended with the category of tense, that is expressed through the Continuous model «to be + Ving». This form can have numerous meanings including the duration of an action, its repetition, simultaneousness, a planned action, an intention to do something, etc. So, the Continuous tense is polysemantic that is extremely helpful in the poetic discourse molding.

The poetic discourse is defined as a subtype of the literary discourse which is characterized by a number of literary devices aimed at making an aesthetic influence on the addressee, mostly through the written form, and the fact that the contact between a writer and a reader is established not immediately. These features increase the number of functions for the text. Mental peculiarities of a writer as well as of a nation are clearly expressed in the poetic discourse as it is based mainly on a person's emotions and feelings.

That means that poetic and emotional functions of the language are exercised in the poetic discourse. Emotional state is one of the extralingual factors influencing the discourse and, actually, causing discourse molding. As for the poetic function the most significant peculiarities of the poetic discourse are the following: metaphorism and bright imaginary of the text, its implicity, suggestion, and associativity. Rhythm, phonetic tropes, unusual syntactic constructions, incoherent train of thoughts are also important features of poetic texts.

«Філологічні трактати», Том 10, № 3 ' 2018 
It should be mentioned that, first of all, the modern American poetry (i. e. literary works of the XXI century) is aimed not at giving aesthetic pleasure but at highlighting social problems. The everyday life with all its details mostly makes the topic. The changes, that had happened in the poetry of the XXI century, affected syntactic connections and poetic form as well as ways of imaginary creation, peculiarities of tropes and choice of words, etc.

For example, Rick Barot uses neutral words in his poem «Ode with Interruptions», avoiding both offensive and bookish words. The writer admits that it was a mistake to think that there are no everyday details in poetry:

I used to think that to write poems, to make art, meant trying to transcend the prosaic elements of the self, to arrive at some essential plane, where poems were supposed to succeed. I was wrong [4]

The poem of Pattiann Rogers «Achieving Perspective», however, is rich in bookish and even scientific language units requiring extra knowledge for correct meaning interpreting:

The galaxies of the Cygnus A cluster

Are colliding with each other in a massive swarm

That it would take 40,000 years full of gathering

Into leaf and dropping, full of pulp splitting

And the hard wrinkling of seed, of the rising up

Of wood fibers and the disintegration of forests..

...Of this room are being swept away now,

Molecule by molecule, in a slow and steady wind

...

Somewhere millions of miles beyond the dimness

Of the sun, the comet Biela, speeding

In its rocks and ices, is just beginning to enter

The widest arc of its elliptical turn

[4]

Lexical units from the sphere of astronomy, radio astronomy, biology add to the poem's secrecy and precision. They trigger an addressee's imagination creating bright visual images looking like a science-fiction movie.

But in most cases, there can be seen a tendency to simplify poetry and to make it more similar to colloquial conversation. This trend has affected also grammar structure of the poetic texts. The following analysis will be focused on the Continuous form of the verb, as this is the object of the study.

In the poetic texts under analysis, the Simple tenses (Present, Past, Future) are most often used tense forms:

- The sun is up so soon to take away the moon [12] (a regular, recurring action; a law of nature);

- She is often the object of my dream but her face is unseen [12] (a regular, recurring action; the word often is a marker);

- My wife wants a bird [12] (a statement of fact).

The Present, Past, or Future Continuous forms also can be used, that is proved by the following examples:

- Canaries and finches all are flying / Around in my mind [12] (the action takes place at the very moment of speech);

- The galaxies of the Cygnus A cluster / Are colliding with each other in a massive swarm / Of interpenetrating and exploding catastrophes [4] (changes are going on for a long time);

- And I was hoping that she would stay longer [12] (the action that took place at some particular time in the past).

Such tense forms as Present Perfect and Past Perfect are used more often than Future Perfect: 
- What error have we made in this communication we set? / Have we entombed our minds into this deep green sea [12] (the action has been done before and there is a result for the present moment);

- I found today what I had sold [8] (an action was preceded by another action in the past);

- I will have run all way / to a future perfect [13] (the action will have lasted until a particular moment in the future).

Moreover, a modern poetic text is often devoid of any rhyme, rhythm, or poetic form (i.e. the text is written not in stanzas but in ordinary lines). Everyday topics cause using colloquial speech style, including slang words, word-groups, and shortenings, jargonisms and vulgarisms; workaday «not-poetic») moments can be described. Modern poets often deliberately omit spelling and grammatical rules, emphasizing "down-to-earth" nature of the poetry that used to be considered a high ideal.

This «down-to-earth» nature causes simplifying of the grammatical structure as well, that is why the Continuous tense is used less frequently than Simple tense, and the Perfect Continuous tense can be seen less frequently than the Perfect tenses.

25 poems have been analyzed for the study. 296 verbs in different tense-forms have been found. More than half of them are used in Present Simple (54\%), the second most frequently used tense is Past Simple (19\%), and the third one is Present Continuous $(16 \%)$. Other tense forms occur with similar frequency and they are not numerous.

The popularity of Present Simple can be illustrated by the following extract from the poem of Cliff Rhodes «The sun, the Moon, the Dream»:

Layers of fantasy and phobia rule the night but soon

There is that quiet place where love is still in bloom.

She takes my hand and we glide together through room

After room of a house so big but neither she nor I can move [12].

Present Simple can be used not only for denoting regular or recurring actions but also for denoting duration. In such a case, this tense form plays the role of Present Continuous, as it happens in Pattiann Rogers' poem «Achieving Perspectives»:
And when you look at me
I try to recall that at this moment
Somewhere millions of miles beyond the dimness
Of the sun, the comet Biela, speeding
In its rocks and ices, is just beginning to enter
The widest arc of its elliptical turn [4].

According to the words «at this moment ... the comet Biela ... is just beginning to enter/ The widest arc», the action is going on at some particular time, this is not a regular action. Still Present Simple occurs in the first part of the sentence «when you look at me / I try to recall that».

The percentage of the tense forms usage is as follows: Present Continuous $-16 \%$, Past Continuous $-2 \%$, Future Continuous $-0,5 \%$.

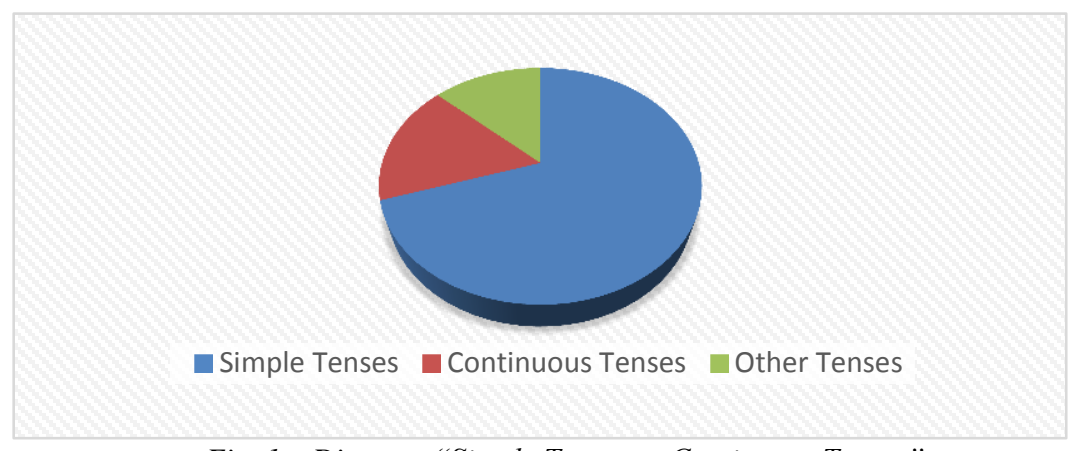

Fig. 1 - Diagram "Simple Tenses vs Continuous Tenses" 
No Future-in-the-Past Continuous form has been found. The ratio of the Simple tenses and the Continuous tenses is visible in the figure 1.

The frequency of Perfect forms usage is as follows: Present Perfect $-2 \%$, Past Perfect $-0,5 \%$, Future Perfect- $0,5 \%$. There are 5 cases of using Present Perfect in the texts under analysis, that accounts for $2 \%$. There was only 1 verb having the Past Perfect form and 1 verb having the Future Perfect form. Present Perfect being the most frequently used form of all the Perfect forms can be explained by the fact that $54 \%$ of all the verbs in the poetic texts are used in Present Simple tense.

The Present Perfect Continuous form is the only case of the Perfect Continuous tenses usage. This accounts for $0,5 \%$ :

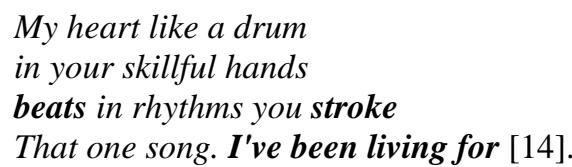

Such an infrequent use of the Perfect tenses can be explained by the fact that these tenses require a specific surrounding, i. e. conditional sentences, a peculiar context when one action is preceded by another one. The trend towards text simplifying also affects the frequency rate.

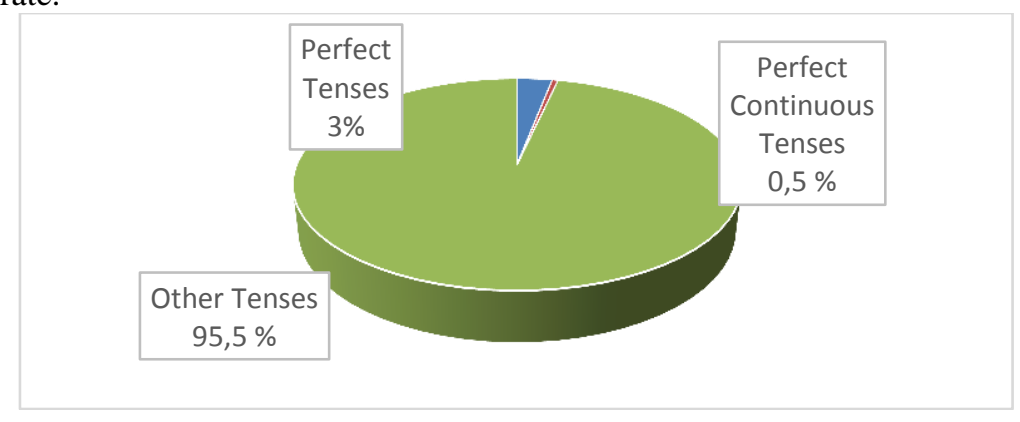

Fig. 2 - "Perfect Tenses vs Perfect Continuous Tenses"

Such a form as Future-in-the-Past is used once $(0,5 \%)$. The ratio of Perfect tenses and Perfect Continuous tenses is shown in the figure 2.

So, the Continuous form is a rare case in the modern poetic texts, accounting for only $19 \%$ and including Present Continuous, Present Perfect Continuous, Past Continuous, and Future Continuous tenses. This can be explained by the tendency to simplify speech, then one tense form can be replaced with another one despite the fact that tinges of the meaning are neglected. For example, Present Simple can be used instead of semantically more appropriate Present Continuous. Everyday topics and colloquial speech style also make for simplifying of the poetic texts.

But, despite the low-frequent usage, the Continuous forms give a new meaning to the poetic texts. This can be seen from the Rick Barot's poem «Ode with Interruptions»:

Someone is in the kitchen washing the dishes.

Someone is in the living room watching the news.

Someone in a bedroom is holding a used stamp with tweezers and adding it to his collection. ...

Someone is taking the ashes out of the small cave of the fireplace, though this might have been a hundred years ago, when the house was new and we didn't live in it. Someone is writing a letter on thin blue paper. Someone is putting down the needle onto a spinning record, just so [4].

At the beginning of the poem, the author describes some everyday situations. Let us assume, the addresser has used Present Simple instead of Present Continuous. Then the 
poem would turn into a list of ordinary actions seeming to be regular due to their semantic meaning (as they are really ordinary ones) and due to the chosen tense form. But, thanks to being used in the Present Continuous form, these verbs make an impression of quite a different kind, making a kind of a chain of scenes from a movie. And, moreover, in this movie, all the action are done by different people but at the same moment. In such a case, a reader comes to the question why the author describes this moment so precisely, why this moment is so important for him. The more everyday situations Rick Barot describes, the more intrigued the reader gets, wondering about why this moment is so significant. The solution comes from the following lines:

\section{On the couch, someone is sleeping. Upstairs, someone is looking into the bathroom mirror - While we were waiting for her surgery to finish, I walked around the hospital and came across a waiting room that had an enormous aquarium... [4].}

As it turns out, someone loved by the author is in surgery at this very moment that is why the moment seems to be endless. Someone lives their routine life, but the time has stopped for the author, waiting is lingering. Rick Barot expertly translates a person's suspended state of painful uncertainty. The recipient dives into this situation and feelings of the addresser. And this reflects the role of Present Continuous in the discourse molding. The significance of this role can be proved also by the fact that if the Continuous form is replaced with another one (let us say, Present Simple or Past Simple), there will be no "thisvery-moment" feeling at all. All the actions will stop going on at the same moment and this moment will not be so important any more. So, there will be no emotional suspension or anticipation of the solution. The meaning of the culmination lines will weaken.

An unusual role is played by the Continuous form in the poem «To Run» by Pamela Milne. The poetess reveals different meaning of the verb «to run», using it in different tense forms.

The dictionary gives the following definitions of the word:

Run: (of people and some animals) to move along, faster than walking, by taking quick steps in which each foot is lifted before the next foot touches the ground; to go quickly or in a hurry; run for sth - to run fast in order to get or avoid something [15].

Pamela Milne uses the verb in Present Simple twice. The same verb is used also in Past Simple, Future Continuous, and Future Perfect, once in each form. The Present Simple, Past Simple, and Future Perfect forms of the verb convey the figurative meaning:

I run from you and the problems [13] (to avoid facing problems, to have no desire to solve them, to pretend as if there is no problem),

I did not run from what was happening [13] (the meaning of the verb «to run» is similar to the previous one, i. e. to avoid the situation, to have no desire to work it out),

I will have run all way to a future perfect [13] (to run along the way of life, in this case, the word-group future perfect does not denote a tense form of the verb, but it is used in its literal meaning: «distant future», «destination point»).

In such a context, the verb «to run» acquires a negative connotation, meaning the necessity to run away from someone or something, to be in a hurry, to run along the way of your life having no opportunity to stop and rest. The described situations seem to be an endless marathon or an escape when running turns into a regular action. It is amazing, but the Continuous form stops this mad running and changes the meaning of the verb into a positive one:

\section{In the future, I will be running \\ on a beach with laughing children. \\ The water is warm and clear. \\ The horizon is pure blue [13].}

The addresser grabs a single moment out of this mad hurry and wants to convey it to the addressee. This time the verb «to run» is used in its literal meaning - to move at a speed. But this running is quite different from three previous marathon-cases. This a happy and 
quiet moment. The reader can easily imagine a warm and sunny scene with parents and children are having fun on the beach. The cloudless sky and warm sea, that are described with the help of Present Simple, add to the duration of the moment, deepening the addressee into the situation. Thus, we are dealing with the discourse, that is molded with the help of Future Continuous.

In conclusion, there is a tendency to simplify the speech that is why the Continuous tense is often replaced with the Simple one. The examples given above, however, have proved the importance of the role of the Continuous form, that can change meaning of the whole sentence or even of the whole text. It also can create a relevant emotional background, allow the recipient to imagine the described events as brightly as possible, deepen the addressee into the discursive event. Even the same verb can have different meanings and emotional connotations when being used in different tense forms.

For the further study the implicit form of the tense-aspect category of the verb in poetic texts can be taken into consideration. That means that the category can be expressed explicitly (with the help of the Continuous form) and implicitly (the case when the verb has no vivid features of the Continuous tense but it still conveys the meaning of simultaneousness, duration, or of a process). In these cases, the category of aspect can be expressed through either lexical means (e.g. with the help of such words as still, now) or grammatical means, such as Participle I, Gerund, non-Continuous verb forms. The implicated aspect meaning can also be an integral semantic component of some words, or it can be seen from the context. And this is a poetic text that helps to solve the question of the dynamics of the discursive development going on with the help of different lexicogrammatical means.

\section{ФОРМА CONTINUOUS У АМЕРИКАНСЬКОМУ ПОЕТИЧНОМУ ДИСКУРСI ХХІ СТОЛІТТЯ}

О. В. Попова, канд. філол. наук, дочент;

Ю. А. Лазуткіна, студентка, ПР-51

Сумський державний університет,

вул. Римського-Корсакова, 2, м. Суми, 4000, Україна

E-mail: o.popova@gf.sumdu.edu.ua; lazutkinayulia@gmail.com

У статті проводиться дослідження американського поетичного дискурсу ХХІ століття з подальшил з'ясуванням ролі, яку відіграє категорія аспектуальності в прочесі творення иього дискурсу. Актуальність обраної тематики зумовлена, передусім, домінуванням функціональної парадигми у сучасній лінгвістиці, а відтак, $i$ зосередженням на вивченні мовних складників із подальшим їх «зануренням $y$ життя» та на взаємозв 'язку мовного та мовленнєвого рівнів крізь призму дискурсу.

Поетичний дискурс визначається як підвид художнього дискурсу, щчо базується головним чином на емочіях та почуттях і якнайкраще відображає ментальні особливості як окремого письменника, так нації в цілому. Тобто, у поетичному дискурсі реалізуються поетична та емотивна функції мови. Щодо емотивної функції, то емоційний стан є одним з екстралінгвальних чинників, щзо впливають на дискурс, фактично спонукаючи до його утворення.

Ситуація, описана у вірші, так чи інакше пов'язана із ситуацією, в якій цей віри твориться митцем. Таким чином, перед читачем постає два завдання: інтерпретувати подану за допомогою поетичних образів інформацію, $i$, наскільки це можливо, зануритися в ситуацію, в якій вірш створювався, відшукати можливу інформацію про адресанта, його оточення, положення $і$ т. д. Зокрема, зануритися в ситуацію допомагає форма англійського дієслова Cопtіпиоия, щзо розглядається як точка перетину категорій часу та аспектуальності і сприяє творенню поетичного дискурсу. У статті аналізується семантика та функиії иієё форми.

Стаття написана в рамках теми дослідження «Механізми впливу інститутів громадського суспільства на євроінтеграичйні процеси в Украӥні» №15.01.10-02.16/18.3П.

Ключові слова: адресант, адресат, граматичне значення, лексичне значення, категорія аспектуальності, категорія часу, поетичний дискурс, тривала форма дісслова 


\section{ФОРМА CONTINUOUS В АМЕРИКАНСКОМ ПОЭТИЧЕСКОМ ДИСКУРСЕ ХХI ВЕКА}

Е. В. Попова, канд. филол. наук, доцент;

Ю. А. Лазуткина, студентка

Сумской государственный университет,

ул. Римского-Корсакова, 2, г. Сумы, 4000, Украина

E-mail: o.popova@gf.sumdu.edu.ua; lazutkinayulia@gmail.com

В статье проводится исследование американского поэтического дискурса XXI века с дальнейшим выяснением роли, которую играет категория аспектуальности в процессе создания этого дискурса. Актуальность избранной тематики обусловлена, прежде всего, доминированием функииональной парадигмы в современной лингвистике, а отсюда, и сосредоточением на изучении языковых составляюших с дальнейшим их «погружением в жизнь» и на взаимосвязи языкового и речевого уровней сквозь призму дискурса.

Ситуация, описанная в стихотворении, так или иначе, связана с ситуацией, в которой это стихотворение создается твориом. Таким образом, перед читателем возникает два задания: интерпретировать информащию, поданную с помощью поэтических образов, и, на сколько это возможно, погрузиться в ситуачию, в которой это стихотворение создавалось, отысккать возможную информацию об адресанте, его окружении, положении и т.д.. Погрузиться в ситуацию помогает форма английского глагола Cопtіпиои, которая рассматривается как точка пересечения категорий времени и аспектуальности и сопутствует созданию поэтического дискурса.

Статья написана в рамках темь исследования «Механизмы влияния институтов гражданского общества на евро интеграционные проиессы в Украине» №15.01.10-02.16/18.3П.

Ключевые слова: адресант, адресат, грамматическое значение, длительная форма глагола, лексическое значение, категория аспектуальности, категория времени, поэтический дискурс.

\section{СПИСОК ВИКОРИСТАНИХ ДЖЕРЕЛ}

1. Блох М. Я. Теоретическая грамматика английского языка / М. Я. Блох. - М. : Высшая школа, $1983 .-$ $383 \mathrm{c}$.

2. Хаймович Б. С. Теоретическая грамматика английского языка / Б. С. Хаймович, Б. И. Роговская. - М. : Высшая школа, 1967. - 300 с.

3. Kennedy A. G. Current English / A.G. Kennedy. - Boston, New York, Chicago, London : Ginn., 1935. - 737 p.

4. Poetry Foundation. [Електронний ресурс]- Режим доступу: https://www.poetryfoundation.org/poets/pattiann-rogers (дата звернення 10.07.2017).

5. Jespersen O. A modern English Grammar on Historical Principles / O. Jespersen. - Copenhagen : E Munksgaard, 1949. Reprinted in Great Britain, 1961. - Part IV, volume III. - 440 р. [Електронний ресурс] Режим доступу: http://arrow.latrobe.edu.au:8080/vital/access/manager/Repository/latrobe:34325 (дата звернення 10.07.2017).

6. Smith Jeane L. The Moonlight Diary, collected poems 2013 // All Poetry. [Електронний ресурс] - Режим доступу: https://allpoetry.com/poem/12490235-The-Moonlight-Diary--collected-poems-2013-by-Jeane-L.Smith (дата звернення 21.07.2017).

7. Ильиш Б. А. Современный английский язык: теоретический курс / Б. А. Ильиш. - 2-е изд., испр. и доп. - М. : Издательство литературы на иностранных языках, 1948. - 348 с.

8. Poem Hunter.com. [Електронний ресурс]- Режим доступу: https://www.poemhunter.com/ (дата звернення 21.07.2017)

9. You have a student who is constantly disrupting the class by talking out of turn...// Chegg Tutors [Електронний ресурс]- Режим доступу: https://www.chegg.com/tutors/English-questions/You-have-astudent-who-is-constantly-disrupting-the-class-by-talking-out-of-turn-and-exhibiting-off-task-behaviorduring-direct-instruction-and-collaborative-group-work-This-behavior-is-impeding-the-process-of-teachingand-learning-in-your-classroom-and-y--V5L0U/ (дата звернення 07.01.2018).

10. The President of Ukraine is arriving in Georgia today // Channel 1. [Електронний ресурс] - Режим доступу: http://old.1tv.ge/en/news/view/170102.html (дата звернення 17.08.2017).

11. The government is going to counter 'misinformation' about GMO foods // The Washington Post. [Електронний ресурс] - Режим доступу: https://www.washingtonpost.com/news/wonk/wp/2017/05/03/thegovernment-is-going-to-try-to-convince-you-to-like-gmo-foods/?utm_term=.e46c03c8b7a7 (дата звернення 17.08.2017).

12. Rhodes C. Selected Poems, Stories, \& Writings of Cliff Rhodes - II / C. Rhodes. - Lulu.com, 2008. - 172 p [Електронний ресурс] - Режим доступу: https://books.google.com.ua/books?id=YT

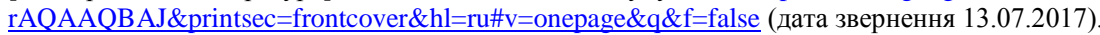

13. Milne P. To Run / Tenses // Poets Online Archive. [Електронний pecypc]- Режим доступу: https://web.njit.edu/ ronkowit/poetsonline/archive/arch_tenses.html (дата звернення 12.07.2017).

14. Smith Jeane L. The Moonlight Diary, collected poems 2013 // All Poetry. [Електронний ресурс] - Режим доступу: https://allpoetry.com/poem/12490235-The-Moonlight-Diary--collected-poems-2013-by-Jeane-L. Smith (дата звернення 21.07.2017).

15. Cambridge Dictionary. [Електронний ресурс] - Режим доступу: https://dictionary.cambridge.org/ (дата звернення 10.07.2017) 


\section{REFERENCES}

1. Blokh M. Ya. (1983). Theoretial Grammar of English. Moscow : Vysshaiia shkola, 383 p.

2. Khaimovih B. S., Rogovskaiia B. I. (1967). Theoretical Grammar of English. Moscow : Vysshaiia shkola, 300 p.

3. Kennedy A. G. (1935). Current English. Boston, New York, Chicago, London : Ginn., 737 p.

4. Poetry Foundation. [Electronic resource]. URL : https://www.poetryfoundation.org/poets/pattiann-rogers (Date of watching 10.07.2017).

5. Jespersen O. (1949). A modern English Grammar on Historical Principles. Copenhagen : E. Munksgaard, Reprinted in Great Britain, 1961. - Part IV, volume III. - 440 p. URL http://arrow.latrobe.edu.au:8080/vital/access/manager/Repository/latrobe:34325 (Date of watching 10.07.2017).

6. Smith Jeane L. The Moonlight Diary, collected poems 2013. All Poetry. URL: https://allpoetry.com/poem/12490235-The-Moonlight-Diary--collected-poems-2013-by-Jeane-L.-Smith (Date of watching 21.07.2017).

7. Ilish B. A. Modern English : Theoretical Course / B. A. Ilish. $-2^{\text {nd }}$ ed., corrected. - M. : Izdatelstvo literatury na inostrannykh yazykakh, 1948. - 348 p.

8. Poem Hunter.com. [Electronic resource] / Access mode : https://www.poemhunter.com/ (Date of watching 21.07.2017).

9. You have a student who is constantly disrupting the class by talking out of turn... Chegg Tutors. - URL: https://www.chegg.com/tutors/English-questions/You-have-a-student-who-is-constantly-disrupting-the-classby-talking-out-of-turn-and-exhibiting-off-task-behavior-during-direct-instruction-and-collaborative-groupwork-This-behavior-is-impeding-the-process-of-teaching-and-learning-in-your-classroom-and-y--V5LOU/ (Date of watching 07.01.2018).

10. The President of Ukraine is arriving in Georgia today . Channel 1. - URL http://old.1tv.ge/en/news/view/170102.html (Date of watching 17.08.2017)

11. The government is going to counter 'misinformation' about GMO foods // The Washington Post. [Electronic resource] / Access mode : https://www.washingtonpost.com/news/wonk/wp/2017/05/03/the-government-isgoing-to-try-to-convince-you-to-like-gmo-foods/?utm_term=.e46c03c8b7a7 (Date of watching 17.08.2017).

12. Rhodes C. Selected Poems, Stories, \& Writings of Cliff Rhodes - II / C. Rhodes. - Lulu.com, 2008. - 172 p [Electronic resource]

URL https://books.google.com.ua/books?id=YT_rAQAAQBAJ\&printsec=frontcover\&hl=ru\#v=onepage\&q\&f=fals e (Date of watching 13.07.2017).

13. Milne P. To Run/ Tenses. Poets Online Archive. [Electronic resource]. URL: https://web.njit.edu/ ronkowit/poetsonline/archive/arch tenses.html (Date of watching 12.07.2017).

14. Smith Jeane L. The Moonlight Diary, collected poems 2013. All Poetry. [Electronic resource]- URL: https://allpoetry.com/poem/12490235-The-Moonlight-Diary--collected-poems-2013-by-Jeane-L.-Smith (Date of watching 21.07.2017).

15. Cambridge Dictionary. [Electronic resource] - URL: https://dictionary.cambridge.org/ (Date of watching 10.07.2017).

Надійшла до редакиії̈ 5 травня 2018 р. 